\title{
THE FORM AND MEANING OF GEBYOG PATANGARING IN RELATION TO THE SACRED ROOM AT THE JAVANESE HOUSE IN SURAKARTA
}

\author{
Joko Budiwiyanto $^{1 *}$ \\ ${ }^{1}$ Indonesian Institute of the Arts, Surakarta \\ "budiwiyanto.joko@gmail.com ${ }^{1}$ \\ * Corresponding Author
}

\begin{abstract}
The study, titled The Form and Meaning of Gebyog Patangaring in Relation to the Sacred Room at the Javanese House in Surakarta, was prompted by the Gebyog Patangaring, which differs from other gebyog forms seen in other Javanese households. These unique characteristics include its position in a sacred site, its unique shape, function, and decoration with meaningful themes. The goal of this research is to figure out the shape and significance of the Javanese dwelling Gebyog Patangaring. Interpretive qualitative research was applied to attain the goals. Surakarta, Wonogiri, Sragen, Sukoharjo, and Karanganyar are among the research places. Sources of data extracted include informants and artefacts. Data collection techniques used in-depth interviews and observation techniques. The analysis technique uses descriptive qualitative and interpretive. The results showed that the shape of the Gebyog Patangaring tends to protrude inward, the shape is symmetrical, in the middle there is a door, the top of the door tends to be decorated with ornaments with snakes, plants, and birds motifs. The meaning of gebyog symbolizes fertility.
\end{abstract}

Keywords: Shape, Meaning, Gebyog Patangaring, Javanese House.

DOI: $10.7176 / \mathrm{ADS} / 95-06$

Publication date:October $30^{\text {th }} 2021$

\section{INTRODUCTION}

Gebyog is a type of Javanese house wall composed of patterned wooden planks. Gebyog is virtually identical in terms of fundamental form or pattern. The differences are seen in the form pattern, kind of material, material quality, size, carving method, decoration, motif, and colour. Despite the fact that Gebyog has the same fundamental structure, each region has its own personality. For example, Gebyog in Surakarta City is dominated by the style of the Surakarta palace and the prince's court. The Gebyog in the priyayi's Sukoharjo region has a distinctive layout; the door is encircled by tiny wood and glass panels that appear to create a centre pattern. Gebyog in the Wonogiri district is unlike any other. The sabukan is another name for the Wonogiri gebyog shape. Because there is a horizontal direction panel in the centre of the gebyog, it is considered to be in the shape of a sabuk (belt) when viewed as a whole. There are gebyog places that are formed like rows of doors, unlike in the Karanganyar and Sragen localities. In Surakarta and Yogyakarta, the gebyog form with a wide panel pattern that extends as high as the door, with the top panel of the door (tebeng) consisting of panels that follow the door panel pattern, is nearly ubiquitous.

When compared to other types of gebyog in Javanese house, the Gebyog Patangaring has unique qualities. The position in a sacred area (krobongan), the form protrudes inward, the function is sacred, and it is designed with special motifs that are full of significance and are sacred are just a few of the unique features. Gebyog 
Patangering is not only a space divider and decorator, but it also has a lot of symbolism. Various motifs, such as tendrils, flowers, snakes, and birds, decorate Gebyog Patangering. Thus, the study of the form and meaning of Gebyog Patangaring with the sacred space of this Javanese house is very interesting to study.

\section{OBJECTIVE}

The objective of this research is to figure out the shape and significance of the Javanese house Gebyog Patangaring.

\section{METHOD}

The Surakarta area was studied, which included the royal palace complex of Kasunanan Surakarta Palace dalem kepangeranan $^{1}$, priyayi houses in Laweyan, and common people's cottages in the villages of Sukoharjo, Karanganyar, and Sragen districts. Descriptive and interpretative qualitative research are the methods used. Sources, artefacts, and literature were all used to collect data. The major source is data included in the sources in the form of words, acts, expressions, and events related to the goal of inquiry (objects/primary source).

In-depth interviews (Sutopo, 2002), observation (Soedarsono, 2001), and literature research were also utilised to obtain data. After gaining authorization from the Javanese cultural organisation Kraton Kasunanan Surakarta, interviews were conducted on chosen sources, including GPH Puger. GPH Puger was a key figure in the postfire (after the 1978) rebuilding of Surakarta's Kasunanan Palace. He's also an authority in Javanese architecture and culture. The Javanese cultural institution, Kraton Kasunanan Surakarta, has asked GPH Puger to be consulted in this research as an expert in the field of conservation and development of Javanese architecture and culture. The approach uses descriptive qualitative and interpretive analysis, i.e., analysis that focuses on the definition of meaning, description, clarification, and placement of data in their appropriate contexts (Pitana, 2014).

\section{LITERATURE REVIEW}

(Arifin MA, 2012), "Makna Simbol Ragam Hias pada Gebyok Rumah Tradisional Kudus"2". The gebyog and symbolic meaning of decorating in the Kudus home are discussed in this research. As a result of the Kudus community's distinct culture, the gebyog study are connected with various versions of the Kudus House. The discussion focuses on the decorations carved on the gebyog and their shape and purpose. The stacked krawang carving method is used to create extremely intricate ornamental shapes.

(Budiwiyanto, 2019), Dharsono, Sri Hastanto, and Titis S. Pitana, "The Influence of Hindu, Buddhist, and Chinese Culture on The Shapes of Gebyog of The Javenese Traditional Houses", in the Journal of Arts and Design Studies, Vol. 79, 2019. This article examines the presence of Javanese house gebyog and the cultural influences that impact it, such as Javanese local genius, which is inspired by Hindu, Buddhist, Islamic, and Chinese civilizations. The history of Javanese house gebyog may be traced back to the periods of HinduBuddhist influence in Central Java, Hindu-Buddhist influence in East Java, and Islamic influence. The gebyog's

1 dalem kepangeranan: Prince's house

2 "The Meaning of Ornamental Symbols in the Gebyog of the Kudus Traditional House" 
form varies in style depending on the backdrop that affects it.

(Maharani Tandjung, 2002), Rumah Solo: Rumah-Rumah Klasik Paduan Kultur Jawa-Eropa ${ }^{3}$. Singapore: Times

Editions. The interiors of Solo mansions such as Sasana Handdrawina, Wuryaningratan palace, the private house of the Santosa family owner of Danar Hadi Batik, the Rumahku Hotel in Laweyan, and numerous priyayi residences in Laweyan are included in the book. Several photographs of gebyog from private homes, function halls, and hotels may be found in the interior. This book does not discuss gebyog in terms of its shape and meaning. In the chamber, gebyog is exclusively represented through photographs.

\section{DISCUSSION}

Gebyog Patangering has a unique form and is considered sacred. The symbols in the shape of snake, bird, and kala motifs can be used to determine the meaning of Gebyog Patangering. The motifs are vertically arranged. Heavenly, spiritual, and sublime are the meanings of the vertical arrangement. The horizontal layout denotes a worldly, immanent state of being (Sumardjo, 2014). There are three essential components to its verticaltranscendent structure. There is a dualistic antagonistic pattern in the immanent structure, specifically pairs of twins that confront one other or contradict each other. The snake pattern represents the spiritual ladder that connects people to the spiritual realm. This symbol comes from Mahayana Buddhism and represents a ladder that connects people to the Buddhist realm (Sumardjo, 2014). The spiritual realm is symbolised by the jungle fowl motif. Aside from chickens, you'll occasionally see two bird themes facing each other. The spiritual world of the gods of the sky and the free air are symbolised by two birds facing each other (Sumardjo, 2014).

The back of the Javanese home construction is where dalem ageng may be found. Dalem ageng has three closed rooms: senthong Tengah ${ }^{4}$, senthong Kiwa ${ }^{5}$, and senthong Tengen ${ }^{6}$. Senthong Tengah is a chamber containing a bed, bolsters, cinde cloth bed linen, mosquito nets/curtains, hoods, and bowls, but it is not used for sleeping. Senthong Tengah is also known as krobongan. A pedharingan (rice storage container), a couple of bridal sculptures (loro blonyo), a jug, senthir, a pair of sewu lamps, and kecohan or paidon are all put in front of the krobongan. On the upper side of the amben ${ }^{7}$, an engraving or picture of an eagle is placed. Senthong Tengah is regarded as a sacred site by the Javanese. For the Javanese, krobongan is a sacred space because one of them is utilised to preserve various types of treasures that the family considers precious and sacred. The heirlooms take many forms, depending on the socioeconomic standing of the family. Spears, giant umbrellas, and keris are among the relics kept in the krobongan. The most sacred royal relics are likewise kept in this krobongan, just as they are at the palace (GPH Puger, Interview 2020).

Because there is a bed within the krobongan, it is also known as pasren or pasarean. In Javanese, the word pasren signifies "Dewi Sri's place" (the Goddess of Rice). Dewi Sri is revered as both the Rice Protector and the Goddess of Fertility by the Javanese. According to Santosa, Sri, as the goddess of rice protection, is also the defender of home welfare, therefore rice farming and household culture are inextricably linked (Santosa, 2000). Dewi Sri is a reincarnation of Dewi Kamaratih, Lord Kamajaya's wife. So, this place was provided by the

\footnotetext{
${ }^{3}$ Solo House: Classical Houses Blending Javanese-European Culture.

${ }^{4}$ Tengah: centre

${ }^{5}$ Kiwa: left

${ }^{6}$ Tengen: right

${ }^{7}$ Amben: bed
} 
Javanese people as a symbol of the cosmic event of the union of Dewa Kamajaya with Dewi Kama Ratih as the gods of love and marriage (Mangunwijaya, 1988). Pasren is a holy rite for Javanese brides to sleep on the first night after their wedding as a location to carry on life/perpetuate their children, according to the Javanese people (GPH Puger, Interview 2020). Widayat explains the conception of pasren as a place for Javanese brides as a division of work between men and women in the processing of rice fields and harvests. The land is cultivated by men, and water distribution in the fields is organised by men. Harvest seeds and grains are handled by women. It's tied up (named manten or a bride and groom pair) and kept in senthong. This idea is to keep the life cycle going by having sexual relations (Widayat, 2004).

A pair of bridal sculptures are put in front of the krobongan, which is known as loro blonyo, to represent Kamajaya God and Kamaratih Goddess. Pasren is also known as the amben tengah ${ }^{8}$ because there is an amben in this room that is furnished with cushions and bolsters, bed linen, and curtains for Dewi Sri's seat and also for the first night for Javanese new marriages. The amben tengah is named for its location in the centre of senthong, which is flanked by the right and left senthongs. As a result, the pasren functions as an altar to honour Dewi Sri (GPH. Dipokusumo, interview, 2019).

Krobongan is also known by the name petanèn. Petanèn is derived from the word tani, which implies a site where agricultural fertility is sought (GPH. Puger, interview, 2020). Kendhi Pratala, which meaning a location for water from the earth, is generally found beneath the petanèn. The water at Kendhi Pratala has been prayed for and is known as lohwati, which means "water of prosperity". During the wiwit ritual, rice is harvested for the first time and stored in Petanèn. The harvested rice will be preserved on the farm as rice seed for the following growing season. The rice seeds that have been preserved at this petanèn in the hopes of getting Dewi Sri's blessings, so that when they are planted the next season, they would become excellent, fertile seeds, and the harvest will be plentiful. The figure of Sri is thought to represent the rice reproduction and human reproduction growth processes (Pemberton, 2003). Because of the significance of saving rice for future life to attain sustained wealth, this Sri idea is portrayed by the Rice Methik, which is a symbol of prosperity.

The life cycle ritual, particularly the wedding ceremony, is also associated with Krobongan, which has another word, pasren, petanèn (mantenan). There is a ritual called the krobongan ceremony in the sequence of the Javanese wedding ceremony. The most holy rite in a Javanese traditional marriage is this one. Only the bride and groom's family could observe the krobongan ceremony in the past (G.P.H. Puger. Interview, 2020). Following the Panggih ritual, the customary krobongan ceremony is performed in the petanèn.

The bride and groom perform the dulangan ceremony by bringing each other a dish of yellow rice (Respationo, 1979), then dulang-dinulang (feeding each other), and finally gambuhan (cupping the plates). The objective is to keep them physically and psychologically united (manunggal), as well as in harmony with their life goals. The groom and bride feeding each other exemplifies the bride and groom's personal actions. They then conduct the ngunjuk rujak degan when the dulangan ritual is finished. Groom and bride, in order, do ngunjuk rujak degan, beginning with groom and ending with bride. The rujak is produced from degan (coconut) that the tree is just beginning to yield fruit. The goal of this ceremony is for newlywed to have children right away. The Krobongan ceremony illustrates the process of persons living in a household who must work together to attain their life objectives, offer each other gifts, and manage money (GPH. Dipokusumo, interview, 2019). If

${ }^{8}$ amben tengah: middle bed 
everything in your life is in order, it is hoped that you will soon have a kid (descendant) as a consequence of the dulangan ceremony, which depicts the bride and groom's private activities. Ngunjuk rujak degan is the consequence of the dulangan ceremony in the hopes of obtaining kids. As a result, the krobongan ceremony represents the Javanese family's production and reproduction process, which takes place at the krobongan (pasrèn/petanèn). The bride and groom come out via the gebyog and present themselves in the pendhapa to beg for the community's blessing once they have authorised and acknowledged in petanèn (Mangunwijaya, 1988). As a result, the krobongan plays an important role in the Javanese community as 1) a place to store family heirlooms, 2) a place to store the first rice harvest, and 3) a place to hold life cycle ceremonies, such as the krobongan ceremony (a wedding venue for newlywed couples' first night), and traditional ceremonies of supitan and tedhak sitèn.

The preceding description of Gebyog Patangaring's meaning can be understood as a sacred space's entry. When humans enter a sacred area, they must be holy and clean, according to the Javanese belief system, which is symbolised by kala ornaments. It is not only clean and pure physically, but also clean and pure in heart and soul, when it comes to being holy and pure here. Humans are ready to meet the ruler of the universe in the form of meditation in this pure and holy state. Humans strive to introspect themselves about the past, present, and how to act in the future when meditating. In order to preserve the balance of life in the earth and the afterlife, humanity must keep both bodily and spiritual equilibrium, remembering the sangkan paraning dumadi. Humans are ready to lower their seeds or progeny into a highly recognised place, the krobongan, if they are totally clean.

\section{RESEACRCH RESULT}

Gebyog was initially made out of vertical or horizontally placed hardwood boards. Gebyog is then constructed using hardwood planks that are framed to produce a certain design. These vertically and horizontally framed wooden planks are placed. Wooden planks that are organised horizontally are often found above the entrance, while those that are arranged vertically are found on either side. Tebeng refers to the wooden boards over the entrance. Lung-lungan patterned decorations are commonly seen on Tebeng. There are carving techniques that distinguish krawang from other types of wood carving. The wooden boards on either side of the entrance are usually simple, with floral patterns carved into them sometimes. The gebyog's form, which is made up of these framed wooden planks, then evolves into a variety of gebyog designs.

\section{Javanese House Layout with Gebyog}

The spatial layout of Javanese houses may be classified into two types: single/stand-alone and clusters of Javanese houses. The following is an explanation of the spatial arrangement of the two types of Javanese homes.

\section{a. Javanese home design with a single form.}

The Javanese home is a one-of-a-kind/stand-alone structure. The terrace (emperr) at the front, the dalem ageng in the middle, and three senthongs make up the spatial arrangement (centre, right and left senthongs). Patangaring, krobongan, petanen, and pasren are all terms used to describe Senthong Tengah. Dalem Ageng works as a front desk receptionist. The right senthong is a sleeping chamber, the middle senthong is a holy area (worship room), and the left senthong is a storage chamber for heirlooms. Ordinary 
Javanese people (kawula) usually live in this single-shaped home.

b. The truss pattern is a Javanese home layout style.

Javanese homes have a truss-like spatial layout with front and back buildings. The king's relatives, the wealthy, and the rural nobles all utilised this house design. The kuncungan, pendapa, pringgitan, dalem ageng, and three senthongs make up the layout of Javanese home rooms for the king's relatives and the wealthy from front to back. Houses of the king's family and wealthy individuals in Pendapa are typically available to the public (without walls). The èmpèr (terrace), pendapa, pringgitan, rumah jero/rumah mburi, and three senthongs make up the village priyayi's space layout. Houses in Pendapa's Priyayi village are typically shuttered (walled).

The spatial layout of Javanese homes may be explained as follows when gebyog is present. Gebyog is split into three sections depending on its layout in the arrangement of Javanese homes. The front gebyog, for starters, serves as a barrier between interior and outdoor environments. Gebyog èmpèr is the name of the front gebyog. Second, gebyog pringgitan is the gebyog that separates the space between the pendapa and the pringgitan. Third, patangaring refers to the gebyog, which is placed inside the dalem ageng and serves as a barrier between the dalem ageng and the senthong.

Because the arrangement of these Javanese houses is only found in regular inhabitants, gebyog empèr can only be found in ordinary Javanese houses (kawula). The pendapa is closed when in use, and there is an èmpèr in front. In truss-style Javanese homes with an open pendapa, gebyog is exclusively utilised in the pringgitan and dalem ageng portions. Houses with a closed pendapa and front gebyog are known as èmpèr, gebyog pringgitan between pendapa and dalem ageng (rumah jero/rumah mburi), and patangaring is senthong.

\section{Gebyog Patangaring's aesthetic shape is linked to the socioeconomic layers of Javanese society.}

The socioeconomic strata of the owner determine the form of the Javanese home gebyog. There are three social strata when it comes to the shape of Javanese houses: raja (king), priyayi (noble), and kawula (common people) (Kuntowijaya, 2006). The social group is determined by the home. The size and shape of a home might reveal the owner's socioeconomic status (Tjahjono, 2002). The shape of the home, its equipment, and the interior may all be used to determine the status of the people who live there.

Gebyog Patangering is a tiny limasan house in the king's home (palace) that stands alone in the centre of the dalem ageng. An ornament in the shape of a snake with its tails meeting in the centre, back-to-back, may be found at the peak of the roof. An ornament in the shape of a king's crown decorates the junction of two snakes. The Patangaring wall's frame is carved with flowery patterns, and the panels are glass-covered.

Patangaring in the houses of princes and rich people (priyayi) generally protrudes inward, mostly finished with paint and gold (prada), carved with krawang, smooth, and beautiful. There are carved decorations in the form of snakes and plants, as well as a crown-shaped ornament at the top of the entrance. The gebyog patangering is crafted from high-quality teak wood. The gebyog in Ndalem Kalitan, for example. The Gebyog Patangering protrudes inward in the centre. Tebeng carved krawang with vines growing out of the vase as a theme. Carved panels with lunglungan motifs may be seen on the right and left sides of the krobongan. Krawangan is the carving technique utilised. Brown wood with natural finishing dominates the gebyog's colour scheme. 


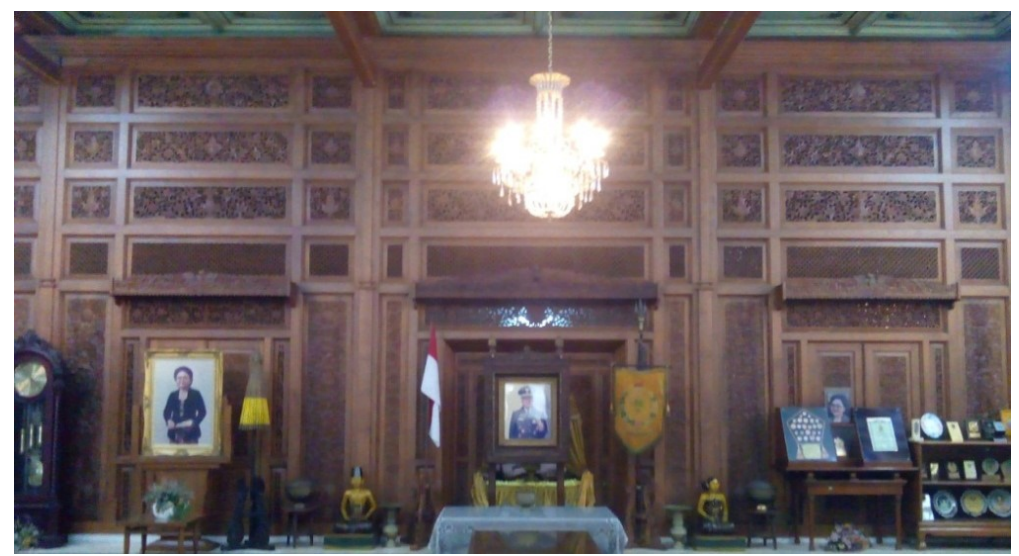

Picture 1: The Gebyog Patangering form at the residence of Ndalem Kalitan, a nobleman in Surakarta (Photo courtesy of Budiwiyanto, 2016).

The gebyog of the priyayi and the gebyog of the prince's residence are nearly identical. Gebyog is generally carved with a high level of detail, with primarily natural colours, gold (prada), and decorations in the form of plants, snakes, and/or birds. The shape of the Javanese priyayi home's Gebyog Patangaring, like in this example, is based on the Javanese priyayi's house in Laweyan, namely Mr. Sumartana's residence. The pattern of the gebyog shape is almost the same as that of the princely house, in that the middle part protrudes inward. The glass door is framed by a carved wooden frame. A lunglungan and a crown motif are carved into the top of the door. A see-through method is used in the carving process. Gold (prada) is used to colour the decorations. The frame is beige in colour with a hint of green accent. The whole colour scheme has a luxury feel to it and appears to be dazzling. The gebyog's overall design is quite opulent, evoking the princes' residences in the Surakarta Kasunanan palace. According to Puger, the residences of people in Laweyan belonging to batik masters were typically made lavish to demonstrate the owner's riches so that he could compete with the princes in the palace (Puger, interview: 2020).

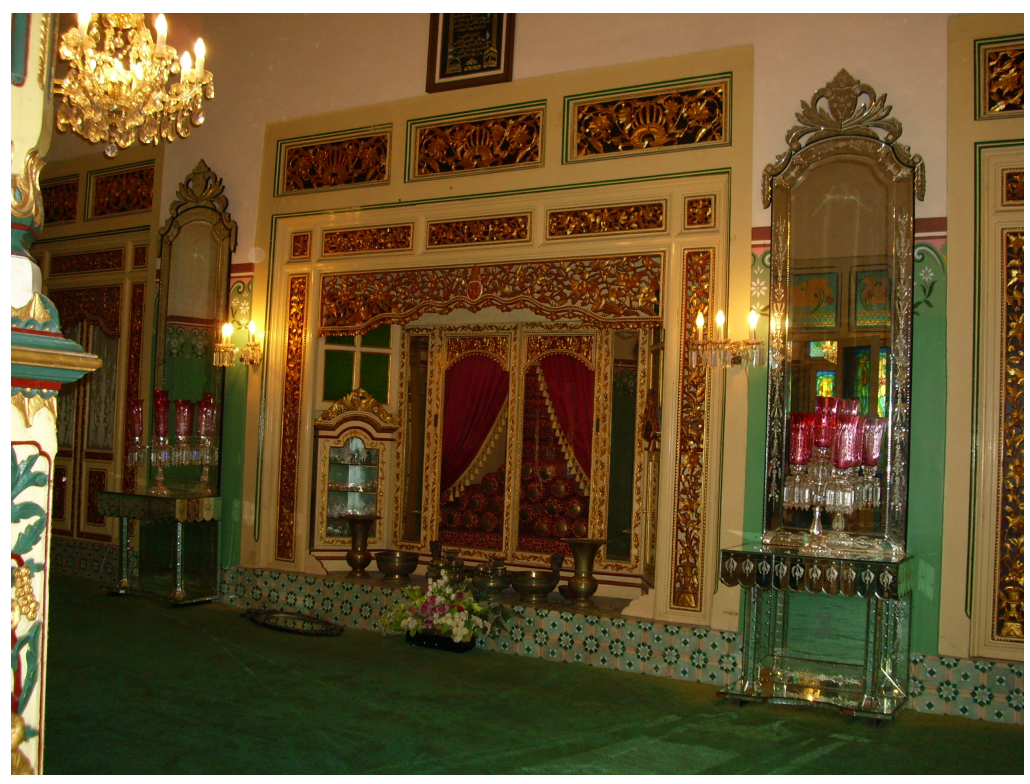

Picture 2: The Gebyog Patangaring in the dalem Sumartanan, a Javanese priyayi in Surakarta's Laweyan neighbourhood (Photo courtesy of Budiwiyanto, 2016). 
In kawula, the Gebyog Patangaring is typically protruding outwards. The door has a modest profile and is gently carved. Gebyog are manufactured mostly of kebon (trembesi, meranti, and mahogany) and jackfruit wood. Gebyog is carved using a simple carving method, rough workmanship, and decorative motifs in the shape of plants and snakes, all in natural colours. The top of the door is decorated with a variety of patterns, including vines (lunglungan), snakes/dragons, kala/kemamang heads, and other holy animals.

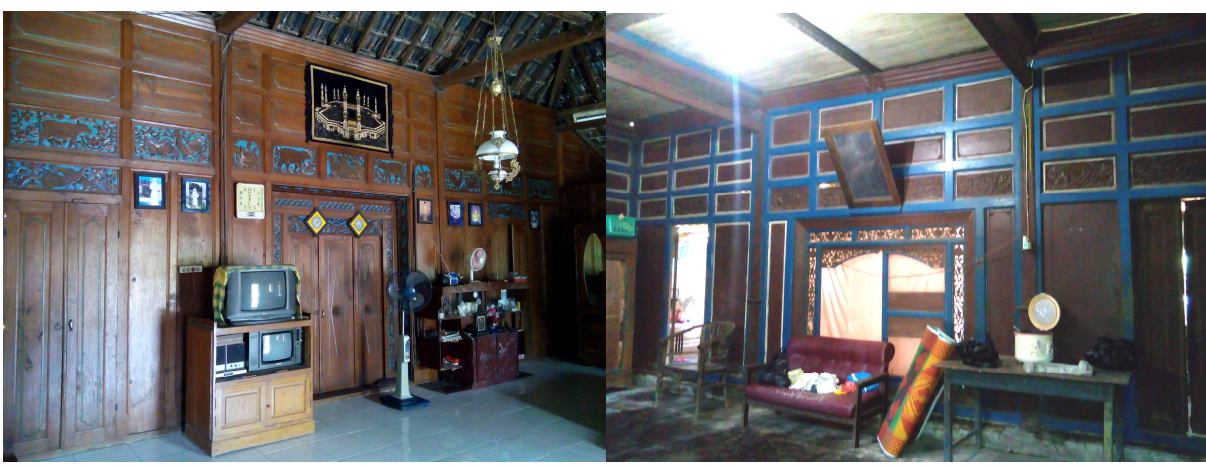

(a)

(b)

Picture 3: The form of Gebyog Patangaring for common people in Central Java's Karanganyar Regency (a) and Masaran's Sragen Regency (b) (Photo courtesy of Budiwiyanto, 2017).

\section{The Significance of Gebyog Patangering in Relation to Sacred Space}

Patangaring is also known by other names, such as senthong tengah, krobongan, petanen, and pasren. Patangaring is a word that is used to refer to a variety of things. All of them depict the sacred marriage ceremony of the Javanese people. In the krobongan, the marriage ceremony is performed as a form of the interaction between men and women as husband and wife. This connection promotes reproduction and life continuation, as well as prosperity and happiness. Sacred motifs such as snakes and kala are carved on patangaring to represent manifestations of the sacred.

Gebyog Patangering as a holy area marker, with sacred animal emblems like as snakes, birds, and kala. Snakes, birds, and kala are symbols that are designed to remind humans that they are in a holy space/space where they are more appreciated in reaching glory. As a result, mankind must preserve mental and emotional clarity, be courteous, and submit to the Almighty. As a result, Javanese people are prepared to create high-quality kids, as seen by the official marriage connection between husband and wife in this krobongan room. So this sign of fertility and wealth is portrayed in the notion of Javanese house in the krobongan room, which is adorned by patangaring.

As a result, Gebyog Patangering bears the meaning of a sacred place entrance door. When humans visit a sacred area, they must be holy and pure, according to the Javanese. It is not only physically clean and pure in the sense of being holy and pure here, but it is also clean and pure in the heart and thought. Javanese people are clean and holy; therefore, they are prepared to meditate with the universe's master. Meditation allows people to reflect on the past, present, and future through thinking about the past, present, and future actions. As a result, humanity must preserve both bodily and spiritual equilibrium in order to sustain the balance of life in this world and in the hereafter, remembering the sangkan paraning dumadi. Humans are ready to lower their seeds or children in a highly recognised space, the krobongan, if they are totally clean. 


\section{CONCLUSION}

The Gebyog Patangering technique of the Javanese might indicate their social position. The form, kind of material used, working techniques, finishing, and types of decorations all reveal the socioeconomic strata. The Gebyog Patangering's form tends to thrust outwards. The door is constructed of teak wood and is low and carved with tendrils. The decorative themes on gebyog include vines (lunglungan), snakes/dragons, kala/kemamang heads, and other holy creatures. The entry to the sacred place, especially the krobongan, is symbolised by Gebyog Patangering. For the Javanese people, the krobongan is adorned with Gebyog Patangaring, which represents fertility and wealth. On the first night of their marriage, Javanese women utilise Krobongan as a bed to bring down their seeds or offspring in the form of having sex with their husband and wife.

\section{BIBLIOGRAPHY}

Arifin MA, Z. (2012). Kajian gebyok dan makna simbol ragam hias pada rumah kudus. Disprotek, 5(2), 44-60. digilib.uns.ac.id

Budiwiyanto, J. (2019). The Influence of Hindu, Budhist, and Chinese Culture on the Shapes of Gebyog of the Javenese Traditional Houses. Arts and Design Studies, 79, 70-78. https://doi.org/10.7176/ads/79-09

Kuntowijaya. (2006). Raja, Priyayi, dan Kawula. Ombak.

Maharani Tandjung, K. (2002). Rumah Solo: Rumah-Rumah Klasik Paduan Kultur Jawa-Eropa. Times Editions.

Mangunwijaya, Y. B. (1988). Wastu Citra, Pengantar ke Ilmu Budaya Bentuk Arsitektur, Sendi-sendi Filsafatnya beserta Contoh-contoh Praktis. Gramedia.

Pemberton, J. (2003). Jawa” On The Subject of Java. Mata Bangsa.

Pitana, T. S. (2014). Teori Sosial Kritis Metode dan Aplikasinya. STAIN Press.

Respationo, S. (1979). Upacara Mantu Jangkep Gagrag Surakarta. Effhar Publishing.

Santosa, R. B. (2000). Rumah: Membaca Makna Rumah Jawa. Yayasan Bentang Budaya.

Soedarsono, R. . (2001). Metodologi Penelitian seni Pertunjukan dan seni Rupa. Masyarakat Seni Pertunjukan Indonesia.

Sumardjo, J. (2014). Estetika Paradoks. Kelir.

Sutopo, H. (2002). Metodologi Penelitian Kualitatif, Dasar Teori dan Terapannya dalam Penelitian. Sebelas Maret University Press.

Tjahjono, G. (2002). Indonesian Heritage: Arsitektur. Buku Antar Bangsa untuk Grolier International, Inc. Widayat, R. (2004). Krobongan Ruang Sakral Rumah Tradisi Jawa. Dimensi Interior, Vol 2,(No. 1, Juni.).

Resource List

G.P.H. Puger, pengageng parentah kraton Kasunanan Surakarta, ahli bangunan Jawa dan budaya Jawa.

G.P.H. Dipokusumo Putra dalem Sinuhun XII, ahli budaya Jawa, rumah Jawa. 